
\title{
Small Scale Enterprise Finance Sources and Constraints in Ethiopia, Case Study of Addis Ababa
}

\author{
Yirgalem Tadele Gerba ${ }^{1}$, P. Viswanadham (M.Com, MBA, Ph.D) ${ }^{2}$ \\ ${ }^{1} \mathrm{Ph} . \mathrm{D}$ Candidate, Department of Commerce and Management Studies, Andhra University, India \\ ${ }^{2}$ Professor, Department of Commerce and Management Studies, Andhra University, India
}

\begin{abstract}
The main objective of the study is to identify the finance source and constraints of small firms in Addis Ababa, Ethiopia. Both primary and secondary data is employed .To address the basic research objectives mainly primary data is collected using structured questionnaires from 250 small business owner-managers that are selected using stratified random sampling techniques. The collected data is analyzed using descriptive data analysis. The result of descriptive data analysis reveals that, own personal saving is most frequently used sources to raise startup capital for sample small business enterprises in Ethiopia. Borrowing from microfinance institution which is the second frequently used sources of finance to raise startup capital to sample small enterprises. Borrowings from friends, relatives and families are the third frequently used sources to raise start-up capitals to small scale enterprise in Ethiopia. Iquib and Idir are traditional informal financing options in Ethiopia and also used as means sources of startup capital. Borrowing from formal banks is least frequently used source of finance to raise start-up capital. The majority sample small firms are experiencing the difficulty of access to credit facilities due to various reasons such as underdeveloped financial institutions, high collateral to secure the bank loans, high interest on borrowed sum of money and complicated and tedious banks and other financial institution loan application procedures.
\end{abstract}

Keywords: small business, finance source, constraints, Addis Ababa

\section{Introduction}

\subsection{Background of the Study}

The roles of small scale enterprises in economic growth of the country through creating job opportunities, introducing innovation and entrepreneurial skills has been increasingly recognized by the policy makers. According to Berger and Udell (2005), that SMEs and informal sector represents $90 \%$ of the business, contribute over $50 \%$ of GDP and account for about $63 \%$ of employment where as SMEs operating in the formal sector contribute up to 45 per cent of employment and up to 33 per cent of GDP in developing economies in low income countries particularly in Africa (IFC, 2010). Alasadi and Abdelraim (2007) added that the existence of strong small business is necessary for boosting economy. In this regard, the health of small business sector important for overall economic growth potential of the economy.

Though SMEs has paramount importance in the pursuit of economic development irrespective stage of economic development, they will generally tends to exploit entrepreneurship in high income countries whilst in less developed economies they will tends to drive -job creation functions( Ming-Wen Hu,2010).

In the literature of small business there are various factors that constrained the growth of small business firms such as inefficient financial markets, poor provision of infrastructure, inefficient regulation of tax .However, it is argued not all these obstacles equally constraints the growth of small firs. Thus, financial constraints take large share of growth obstacles (Harvie et al, 2013). It is therefore, availability of finance widely acknowledged to development and growth small scale enterprises (Ou \& Haynes, 2006; Cook, 2001). from literature three sources of finance for small firm has been identified: internal sources, such as owner-manager"s personal savings and retained profits (Junjie et al,2008) ,informal outside sources, including financial assistance from family and friends (Abouzeedan, 2003), trade credit, venture capital and angel financiers (He \& baker, 2007), and thence to formal external sources represented by financial intermediaries such as banks, financial institutions and securities markets (Chittenden et al,1996).

\subsection{Statement of the problem}

In the current political and economic environment, jobs are centre of political debts in both developed and developing economies. Thus, the roles of small businesses in creating more jobs is give due considerations but they are unable to create expected job by expanding small business due to various constraints.

According to Malhotra et al (2006), lack of access to finance constrains the growth and competitiveness of micro, small and medium enterprises.

Large number of literatures indicated that Small Enterprises are financially more constrained than large firms and are less likely to have access to formal finance. This potentially constrained their operation and growth (Berger and Udell, 1998; 2003; Beck et al., 2005; Beck and Demirguc-Kunt, 2006). OECD (2006), argued this could be due difference in risk profile and information asymmetries between the firm and lending institution. Financial and institutional development helps alleviate $\mathrm{SMEs}^{\text {ee }}$ growth constraints and increase their access to external finance (Beck and Demirguc-Kunt, 2006) .Moreover, ACCA (2012) revealed that, government; technology and education are key determents factors that influence access to finance. These arguments holds true due the fact that, government plays an 


\section{International Journal of Science and Research (IJSR) \\ ISSN (Online): 2319-7064 \\ Index Copernicus Value (2013): 6.14 | Impact Factor (2015): 6.391}

important role in establishing financial institutions and designing polices in favor of the sector development. It is also arguable that level of education and technology unquestionably enhance the sector development as the level of education influence entrepreneurial ambition and more educated are likely to have higher desire to start business.

In developing country small firms are commonly prone to the problems that were related to infrastructure, finance, human capital and unfavorable macro environment related problems However, access to finance service for SMEs remains severely constrained in many emerging markets (IFC and ACCA, 2012). According to Beck et al., (2005), collateral requirements, bank bureaucracy, high interest rate access to financing for leasing equipments, inadequate credit and access to long term loans are financing obstacles which affect the growth of small firms negatively.

Demirgüç-Kunt and Maksimovic (1998) shows firms in countries where underdeveloped financial institution severely faces external financing than firms in countries with developed institutions. Thus the likelihood of SMEs to bank loans in low-income countries compared to large firms is relatively low and largely relies on internal source of finance ( Harvie et.al.,2013)

The bank remains significant source external finance for SMEs (IFC, 2010), however, bank finance is generally only available to those businesses that can offer collateral or a strong record of generating profit. This would result only few small firms could be advantageous but there must some alternative lending mechanisms for small business firms who do not meet collateral requirements and weak record of profit performance to promote the development of the sector as government seeking the sector to observe more employment opportunity and make use of indigenous technology. Moreover, Malhotra et al (2006) confirms in many countries MSMEs complains lack of access to finance due to lack competitions in banking sectors limits pressure of banks to reach out to MSMES clients, high risk and transaction costs with bank lending to SMEs and lack of collateral among SMEs as pledge. Consequently, their growth and competitiveness remains beleaguered.

Its assumed microfinance is playing great roles in financing such sectors. Despite the increase in credit institution, despite many common challenges that small businesses typically encounter, access to finance being the most notable constraint. In reality, access to finance is one of the few areas of enterprise policy that are truly global (ACCA, 2012). The importance of access finance is critical for the development of small businesses. This would be evidenced in many of the western economy that strong private and public sector development while in other part of the world especially in developing countries the opposite would be experienced, private and SMEs sector development still in its stage infancy and still resulting inefficient financing channel for small business firms. According to IFC (2010) More than 17 million formal SMEs in the emerging market have unmet credit needs .the gap is estimated to be between $\$ 900$ billion and $\$ 1.1$ trillion for SMEs in those markets.
Credit constraints according to OCED (2006) occurred when SMEs cannot obtain financing from the banks, capital market and other suppliers of the finance even when they have capability to use funds productively. In this regard, it $\mathrm{s}$ arguable that economical viable projects have to be restricted even abandoned because of funding. As result, their growth and innovation negatively affected. According to Malhotra et al( 2006), government attempts to address the constraints and offset the inequalities in financial sector policy generally have not yet achieved desire results. Having these gaps in global perspective and considering unique regional insights this paper will design to identify finances sources and constraints of small business firms in Addis Ababa, Ethiopia and give some insights for the policymakers to address the issues and enhance development small scale enterprises sector in the region.

\subsection{Objectives of the Study}

The general objectives of the study to examine finance sources and constraints of small and enterprise in Addis Ababa

\subsubsection{Specific objectives of the study}

- To assess the source of finance to small scale enterprise in Addis Ababa

- To investigate the factors that constrained access to finance in Addis Ababa

\section{Methodology of the Study}

To address the research objectives, survey approach research design is employed in this study.

\subsection{Data Type and Sources}

Both Primary and secondary data were used in this study. The primary data were gathered through structured questionnaires. While secondary data were complained from previous studies, books, bulletins of small scale enterprise.

\subsection{Sampling Techniques}

The Populations of the study were the owners -managers of small scale enterprise in selected five sub-cities Addis Ababa that were approximately 890. Followings Yamane (1967), sample size determination formula, total sample size (n) of 250 is determined. Using proportional sampling allocation, the minimum sample size to be selected for each five sub-cities determined. Finally the minimum sample size allotted for each sub-cities are selected using simple random techniques.

\subsection{Method of Data Analysis}

Due the nature of the variables to be investigated in this study descriptive method of data analysis was employed

\section{Data analysis and interpretations}

\subsection{Sources of finance for small scale enterprises}




\section{International Journal of Science and Research (IJSR) \\ ISSN (Online): 2319-7064 \\ Index Copernicus Value (2013): 6.14 | Impact Factor (2015): 6.391}

Small enterprises can raise Startup capital from the various sources such as connectional banks microfinance institutions, cooperatives, government projects and informal money lenders. Similarly, Ageba and Amha (2006) in their study of MSEs finance in Ethiopia revealed that friends/relatives, suppliers credit, and Iqub (rotating saving and credit associations) are the most important sources of finance and informal money lenders were used rarely likely due to availability better financing options in their terms and conditions .

To capture information regarding the major sources finance to start up , the various sources of finance were been prepared and enterprises were asked to indicate sources of startup capital or whether they ever received credit from each of a given list of sources of finance during start up.

Table 3.1: Descriptive statistics for owners ${ }^{\text {ee }}$ major source startup capital

\begin{tabular}{|c|c|c|c|}
\hline Variable & & Frequency & Percent \\
\hline \multirow{5}{*}{$\begin{array}{l}\text { Finance source } \\
\text { of startup capita }\end{array}$} & Own personal saving & 120 & 48 \\
\hline & Formal Banks & 12 & 4.8 \\
\hline & Microfinance Institution & 83 & 32.2 \\
\hline & Iquib $^{1} \&$ Idir $^{2}$ & 16 & 6.4 \\
\hline & Friends, family \&relatives & 19 & 7.6 \\
\hline Total & & 250 & 100 \\
\hline
\end{tabular}

Source: SPSS output own survey data (2014)

${ }^{1}$ Equib is an informal association established by a small group of people in order to provide substantial rotating funding for members in order to improve their lives and living conditions.

${ }^{2}$ Idir is also informal association established among neighbors or workers to raise funds that will be used during emergencies, such as death within these groups and their families and sometimes used as sources of finance. Iquib and Idir can be characterized as traditional financial associations. While Idir is a long term association, Iquib can be temporary or permanent, depending on the needs of the members.

As can been seen from descriptive table above, own personal saving (48\%) is most frequently used sources to raise startup capital for sample small business Enterprises in Ethiopia. This is contradict to the finding of Ageba and Amha, (2006 ) who revealed friend and relatives are most frequently used sources of finance. Possible explanation own personal saving as most used sources finance would due underdeveloped financial institutions in Ethiopia as well formal banks favored to provide credit to large enterprises. It is also argued that banks in Ethiopia do not find small business enterprises as an attractive clients, mainly due to high transaction costs and fails to pelage collateral securities to borrow the required amount.

Table also depicted that, borrowing from microfinance institution which is about $32 \%$ is the second frequently used sources of finance to raise startup capital to sample small enterprises.

This finding is contradicted to Garoma(2012), finding who revealed, microfinance as least frequently used sources of finance to raise startup capital. One possible explanation why microfinance institution as the second frequently used sources finance next own personal saving would due microfinance institutions which were basically established for the purpose granting loans to MSEs has been growing in their outreach and performance.

Iquib and Idir are traditional informal financing options in Ethiopia. About $6 \%$ of sample respondents noted that Iquib and Idir as sources finance to start up capital.

\subsection{The respondent's response for access to credit facilities}

Tough finance is considered to be the life blood every enterprise, small business in developing countries are suffering due to inadequate finance to operate their business. To know the whether the establishment has no sufficient access to credit the respondents were asked to indicate their feelings using,yes or no "e questioners. The result in table 3.2 revealed that, about 46.8 percent of respondents replied that their establishment has access to credit .while About 53.2 percent of the respondents revealed that there is no sufficient credit facility their establishment.

Table 3.2: descriptive statistics for respondent"s access to credit

\begin{tabular}{|l|l|l|l|}
\hline \multicolumn{2}{|c|}{ There is no sufficient access to credit } & Frequency & Percent \\
\hline & Yes & 117 & 46.8 \\
\hline & No & 133 & 53.2 \\
\hline Total & & 250 & 100 \\
\hline
\end{tabular}

Source: author computation from survey data

\subsection{Respondents Response on the factors that constraints Access Finance}

In table 3.2, we assessed whether there sufficient credit facilities to the establishment. In this section we present the factors that constraints small business access to finance. Thus ,small business access to finance constraints were operationalized as whether there is "no sufficient numbers of banks around establishment, high collateral requirement to secure bank loans, high interest rate, tedious and complicated loan application procedures" which perhaps considered to creates challenges for access finance of small business.

Availability sufficient numbers of banking and other credit institution around the establishment is an important determinates of small business access to finance service. Accordingly, small business owners were asked their feeing whether there is no sufficient numbers of banking and other credit institutions around their establishment. Majority 51\% of the respondents feels that there is no sufficient number of banking and other credit institutions around their establishment, while $36 \%$ of the respondents assume there is sufficient numbers of banking and other credit institution around their establishment. It is obvious that as there was sufficient numbers of credit institution around the establishment, there would be competition among credit institution to provide credit and this in turns leads to access to credit facility of small business.

In the literature of small business, it is clearly indicated that the cost of borrowing had potential impact on firm performance. To this end, information was sought whether the banking and other credit intuitions requires high 


\section{International Journal of Science and Research (IJSR) \\ ISSN (Online): 2319-7064 \\ Index Copernicus Value (2013): 6.14 | Impact Factor (2015): 6.391}

collateral to secure their loans. Table 6.4, indicates that, majority $45 \%$ of the respondents feel that the banks and other credit intuitions don 't requires high collateral to secure their loans, where as $42 \%$ of the respondents assume there the banks and other credit institutions impose high collateral to secure their loans, which in turn leads to difficulty of getting credit.

High cost of borrowing such as high interest rate imposed by banks and credit institutions on borrowed sum of money limits access to credit facility of small business and adversely affects small business performance. The respondents were asked their perception whether the banks and other credit institutions were imposing high interest rate on borrowed sum of the money. Table below indicates that, about $41 \%$ of the respondents perceived that the banks and other credit institutions were not imposing high interest rate on borrowed sum of the money. While $45 \%$ of the respondents perceived that the banks and other credit institutions were imposing high interest rate on borrowed sum of the money.

The banks and credit institutions bureaucratic practices during loan application procedure were possibly determines access to financing service of small business and thereby determines their performance. This is perhaps due to in situation where there is bureaucratic and tedious practice to get credit, more likely few applicants may apply for credit and or loan services.

Accordingly, the information was sought whether there is a bureaucratic and tedious loan application procedure of the bank. Table 6.4, revealed that majority , $43 \%$ of the respondents feels that the bank and other financial institutions practices a bureaucratic and tedious loan application procedure, while $41 \%$ of the respondents perceived that there is no a bureaucratic and tedious loan application procedure of the bank.

Table 3.3: perceived reasons for finance constraints

\begin{tabular}{|c|c|c|c|c|c|c|c|c|}
\hline \multirow{2}{*}{ Response } & \multicolumn{2}{|c|}{ NSNB } & \multicolumn{2}{c|}{ HC } & \multicolumn{2}{c|}{ HIR } & \multicolumn{2}{c|}{ LAPTC } \\
\cline { 2 - 9 } & $\mathrm{f}$ & $\%$ & $\mathrm{~F}$ & $\%$ & $\mathrm{f}$ & $\%$ & $\mathrm{f}$ & $\%$ \\
\hline SDA & 42 & 16.8 & 45 & 18 & 39 & 15.6 & 44 & 17.6 \\
\hline DA & 49 & 19.6 & 59 & 23.6 & 62 & 24.8 & 58 & 23.2 \\
\hline NAND & 32 & 12.8 & 33 & 13.2 & 50 & 20 & 40 & 16 \\
\hline AG & 82 & 32.8 & 51 & 20.4 & 53 & 21.2 & 47 & 18.8 \\
\hline SG & 45 & 18 & 24.8 & 46 & 46 & 18.4 & 61 & 24.4 \\
\hline Total(N) & 250 & 100 & 250 & 100 & 250 & 100 & 250 & 100 \\
\hline Mean & 3.156 & 3.104 & 3.02 & 3.092 \\
\hline Median & 4 & \multicolumn{2}{|c|}{3} & \multicolumn{2}{c|}{3} & 3 \\
\hline Mode & 4 & \multicolumn{3}{|c|}{5} & \multicolumn{2}{c|}{2} & \multicolumn{2}{c|}{5} \\
\hline Std.Devation & 1.37814 & 1.46621 & 1.35163 & 1.44912 \\
\hline
\end{tabular}

Source: Own survey result (2014)

Note that: SDA=strongly disagree, $\mathrm{DA}=$ disagree, NAND=neither agree nor disagree, $A G=$ agree, $S A=$ strongly agree

NSNB= there is no sufficient numbers of banking institution around establishment

$\mathrm{HC}=$ banks and other financial institution requires high collateral to secure the bank loans

HIR= the banks and other financial institutions impose high interest on borrowed sum of money
LAPTC= loan application procedures of the banks and other financial institution is tedious and complicated

\section{Conclusions and Recommendations}

\subsection{Conclusions}

This study is intended to identify the finance source and constraints of small firms in Addis Ababa. Both primary and secondary data is employed .To address the basic research objectives mainly primary data which is collected using structured questionnaires from 250 small business ownermanagers that are selected using stratified random sampling techniques. The collected data is analyzed using descriptive data analysis.

The result of descriptive data analysis reveals that, own personal saving (48\%) is most frequently used sources to raise startup capital for sample small business enterprises in Ethiopia. borrowing from microfinance institution which is about $32 \%$ is the second frequently used sources of finance to raise startup capital to sample small enterprises. Iquib and Idir are traditional informal financing options in Ethiopia. About $6 \%$ of sample respondents noted that Iquib and Idir as sources finance to start up capital. Borrowing from formal banks (4.8\%) is least frequently used source of finance to raise start-up capital.

The majority sample small firms are experiencing the difficulty of access to credit facilities due to various reasons such as underdeveloped financial institutions, high collateral to secure the bank loans, high interest on borrowed sum of money and complicated and tedious banks and other financial institution loan application procedures.

\subsection{Recommendations}

Based on the findings of the study the following recommendations have been forwarded for the policy makers and other stakeholders:

- It is observed small firms are experiencing difficulty of access to credit due various reasons thus, The government should improve the financial intuitions to enhance their lending capacity small business firms

- The traditional means of raising start-up capitals such as Equib and Idir must be encouraged as they are alternative means raising the money when government fails to provide loans to all small scale enterprises.

- It is observed high collateral requirement, high interest rate on borrowed sum and tedious and complicate loan application procedures are important factors that constraints firms access to finance. The government should provide loans to small business firms with no or little collateral requirements once the feasibility of the project is studied well. The government should also impose no or small interest on borrowed sum the money till the firms structured well.

\section{References}

[1] Abdulaziz M. Abdulsaleh \& Andrew C. Worthington (2013). Small and Medium-Sized Enterprises Financing: A Review of Literature, International 


\section{International Journal of Science and Research (IJSR) \\ ISSN (Online): 2319-7064 \\ Index Copernicus Value (2013): 6.14 | Impact Factor (2015): 6.391}

Journal of Business and Management; Vol. 8, No. 14, ISSN 1833-3850 E-ISSN 1833-8119

[2] Abouzeedan, A. (2003). Financing Swedish Small and Medium-Sized Enterprises (SMEs): Methods, Problems and Impact. Paper presented at the 43rd European Congress of the Regional Science Association, Jyväskylä, Finland

[3] Association of Chartered Certified Accountants (ACCA), (2012). Access to finance for SMEs: a global agenda, paper presents the ACCA Global Forum for SMEs.

[4] Beck, Thorsten, Aslı Demirgüç-Kunt, and Vojislav Maksimovic.( 2005). "Financial and Legal Constraints to Firm Growth: Does Firm Size Matter?" Journal of Finance, 60, 137- 177.

[5] Beck, T., A. Demirguc,-Kunt, L. Laeven, V. Maksimovic (2006). „The Determinants of Financing

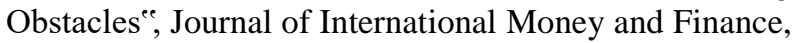
25, Pp.932-952.

[6] Berger, Allen N. and Gregory F. Udell (1998). "The Economics of Small Business Finance: The Roles of Private Equity and Debt Markets in the Financial Growth Cycle.” Journal of Banking and Finance, pp, 22, 613-673.

[7] Charles Harvie ,Dionisius Narjoko and Sothea Oum,(2013). Small and Medium Enterprises ,Access to Finance: Evidence from Selected Asian Economies, ERIA discussion paper series, Oct, 2013.

[8] Chittenden, F., Hall, G. C., \& Hutchinson, P. J. (1996). Small Firm Growth, Access to Capital Markets and Financial Structure: Review of Issues and an Empirical Investigation. Small Business Economics, 8(1), 59-67. http://dx.doi.org /10.1007/Bf00391976

[9] Cook, P. (2001). Medium-Sized Enterprise in Developing Countries. Journal of Developmental Entrepreneurship, 6(1), pp, 17-40

[10]Demirgüç-Kunt, Asli, and Vojislav Maksimovic, (1998). Law, finance, and firm growth, Journal of Finance, 53, 2107-2137.

[11] García-Teruel, P. J., \& Martínez-Solano, P. (2010). Determinants of Trade credit: A Comparative Study of European SMEs. International Small Business Journal, 28(3),

$\mathrm{pp}$,

215-233.

http://dx.doi.org/10.1177/0266242609360603

[12] Garoma, B.F. (2012).Determinants of Microenterprise Success in the Urban Informal Sector of Addis Ababa: A Multidimensional Analysis, ISS PhD Theses, Erasmus University Rotterdam. Retrieved from http://hdl.handle.net/1765/37927

[13] Gebrehiwot Ageba and Wolday Amha (2006).Micro and Small Enterprises (MSEs) Finance in Ethiopia: Empirical Evidence, Eastern Africa Social Science Research Review, Volume 22, Number 1, pp. 63-86

[14]He, W., \& Baker, H. K. (2007). Small Business Financing: Survey Evidence in West Texas. The Journal of Entrepreneurial Finance and Business Ventures, 12(1), 27-54 International Financial Corporation (2012) .IFC and small and medium enterprises.

[15] Junjie Wu, Jining Song, Catherine Zeng, (2008). "An empirical evidence of small business financing in China", Management Research News, Vol. 31 Iss: 12, pp.959 - 975
[16] MING-WEN HU (2010).SMEs and economic growth: entrepreneurship or employment, ICIC Express Letters, Volume 4, Number ,6(A), December,2010 , pp. 22752280

[17] Mohini Malhotra, Yanni Chen, Alberto Criscuolo, Qimiao Fan, Iva Ilieva Hamel, and Yevgeniya Savchenko(2006).Expanding Access to Finance: Good Practices and Policies for Micro, Small, and Medium Enterprises, World Bank Washington, DC, August 2006

[18] OECD (2006), The Small And Medium Enterprise Financing Gap: Theory and Evidence, Vol. 1, OECD, Paris.

[19] Ou, C., \& Haynes, G. W. (2006). Acquisition of Additional Equity Capital by Small Firms - Findings from the National Survey of Small Business Finances. Small Business Economics, 27(2), 157-168. http://dx.doi.org/10.1007/s11187-006-0009-8

[20]Rami Alasadi, Ahmed Abdelrahim (2007).Critical analysis and modeling of small business performance (case study: Syria), Journal of Asia Entrepreneurship and sustainability development, Vol, 3, Issue, 2, ISSN 1176-8592.

[21] Thorsten Beck, (2007). Financing Constraints of SMEs in Developing Countries: Evidence, Determinants and Solutions

[22] World Bank /IFC (2010).Micro, Small, and Medium Enterprises around the World: How Many Are There, and What Affects the Count? Country indicator, 2010

[23] Yamane,Taro (1967).Statistics: An introductoryAnalysis, $2^{\text {nd }}$ ed ,New York ,Harper and Row 